\title{
Absicherung Ihrer Familie
}

Eine schwere Krankheit oder ein Unfall trifft die Familie schwer und hat bei Ausfall des Hauptverdieners oft schwerwiegende finanzielle Folgen. Wissen Sie, welche Leistungen Ihnen und Ihrer Familie zustehen würden? In einer persönlichen Vorsorgeanalyse zeigen wir Ihnen auf, welche Leistungen Ihnen bei Erwerbsunfähigkeit, im Todesfall oder nach der Pensionierung zustehen. Wir decken so Unter- oder Überversicherungen auf und können Massnahmen zum Schutz Ihrer Familie treffen.

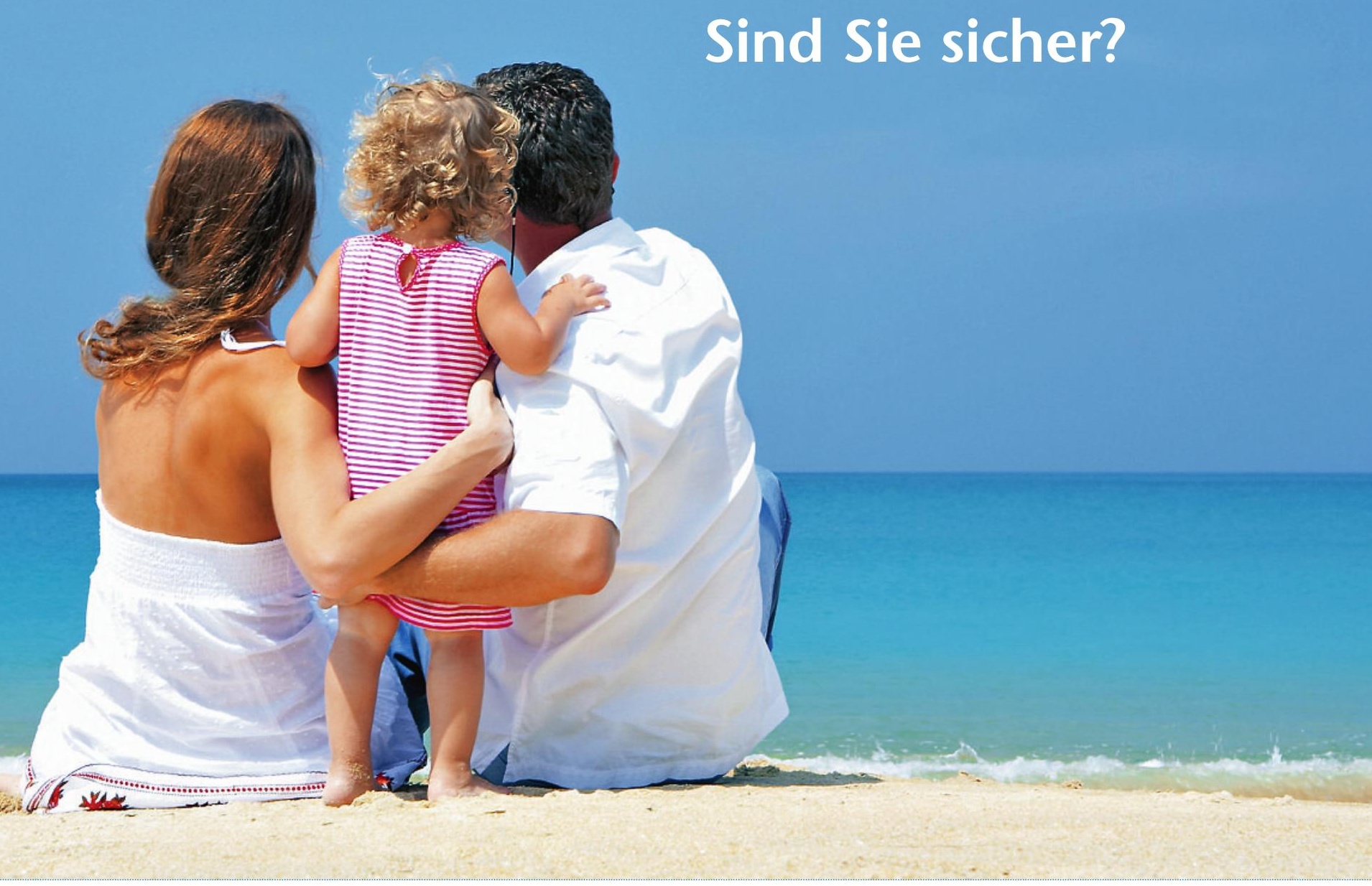

$\square$ Ich will für meine Familie und mich vorsorgen und möchte mich beraten lassen. Bitte rufen Sie mich an.

Vorname/Name

Adresse

PLZ/Ort

Geburtsdatum

Telefon Privat/Geschäft

Beste Zeit für einen Anruf

E-Mail-Adresse

\section{GMH INSURANCE}

Roth Gygax \& Partner AG घ Koordinationsstelle Moosstrasse 2 - 3073 Gümligen

Telefon 0319595000 ․ Fax 0319595010

mail@fmhinsurance.ch n www.fmhinsurance.ch 